\title{
Severity of Leaf Harvest, Supplemental Nutrients, and Sulfur Application on Long-term Leaf Production of Aloe barbadensis Miller
}

\author{
Yin-Tung Wang, \\ Department of Horticultural Sciences, Texas A\&M University System, \\ Agricultural Research and Extension Center, 2415 East Highway 83, \\ Weslaco, TX 78596
}

Additional index words. Aloe vera, leaf initiation, mineral nutrition, micronutrient, soil pH

Abstract. This is the first report on how leaf harvest techniques and sulfur may affect leaf initiation and yield of Aloe barbadensis Miller (syn. Aloe vera L.). Two long-term experiments were conducted to determine the effects of supplemental mineral nutrients, severity of harvest, and sulfur application on leaf yield of this species. Plants were each grown in a 38 -L pot with or without monthly applications of a $20 \mathrm{~N}-8.6 \mathrm{P}-16.6 \mathrm{~K}$ watersoluble fertilizer. In the first experiment, beginning in June 1994 (7 months after initiation), the lower leaves were harvested every 3 months with 12, 15, or 18 leaves remaining per plant. All plants were harvested to 12 leaves at the final harvest in Mar. 1997. Fertilized plants that were harvested to 12 leaves produced 81 leaves each during the 3-year period, whereas those harvested to 15 or 18 leaves each produced 76 leaves. In contrast, each of the nonfertilized plants produced 36 leaves. Fertilization tripled the cumulative weight of harvested leaves over a 3-year period. The initial quarterly and cumulative leaf weights were higher in plants harvested to 12 leaves than those harvested to 15 or 18 leaves. However, this difference diminished and disappeared over time. Fertilized plants harvested to 18 or 15 leaves yielded over $10.8 \mathrm{~kg}$ annually, whereas nonfertilized plants with 12 leaves produced an average of $3.5 \mathrm{~kg}$ leaves per plant. In the second experiment (with or without fertilizer and micronutrient and $0,25,50$, or $100 \mathrm{~g} /$ pot of powdered sulfur per year), plants responded similarly to fertilization as they did in the first experiment. The added micronutrients $(25 \mathrm{~g} /$ pot per year) had no effect on plant growth. The highest rate of sulfur resulted in few leaves being harvested and reduced cumulative leaf weight in fertilized plants, but did not affect the number of harvestable leaves or their total weight in nonfertilized plants. Soil $\mathrm{pH}$ declined from 7.6 to 4.6 as a result of fertilization regardless of the amount of sulfur being applied. In both experiments, plants that received fertilizer had slight cold injury on the abaxial side of some south-facing leaves. The results suggest the importance of fertilizer application to enhance leaf initiation rate. Plants should be harvested to leave no fewer than 15 leaves, preferably 18, on the plant to maintain high leaf yield.

Leaf extracts of Aloe barbadensis have been used in food products, cosmetics, medicines, and so on for centuries. Compounds and extracts from aloe leaves have been reported to accelerate wound healing, manage and treat thermal injuries, and serve as a vehicle to enhance the penetration of drugs into animal tissues (Cera et al., 1980; Winters et al., 1981). Extract from aloe leaves was shown to inhibit ultraviolet-induced immune suppression (Strickland et al., 1999).

Aloe barbadensis is native to South Africa and has been widely grown commercially in tropical and subtropical regions and under protected cultivation in temperate climates. It does not tolerate temperatures at or below freezing. When growing $A$. barbadensis in subtropical areas such as south Texas and

Received 2 July 2007. Accepted 9 July 2007. ${ }^{1}$ Professor of Floriculture and Plant Physiology. ${ }^{2}$ Currently: Matsui Nursery, Salinas, CA. E-mail yintung.wang@gmail.com
In field-grown Easter lily (Lilium longiflorum Thumb.) with an average of 70 leaves, removing the lower 30 to 50 leaves did not affect bulb weight (Wang, 1990). However, bulb weight was reduced by more severe leaf removal to maintain only the top 10 . The growth of anthurium (Anthurium andraenum Andre) flower bud was suppressed by its growing, subtending leaf (Dai and Paull, 1990). Therefore, removing the developing leaf accelerated the emergence and initial growth of the flower bud on this node. Similar studies have not been conducted with Aloe barbadensis to determine how various degrees of leaf harvest would affect leaf production.

The lower leaves of Easter lily were shown to have little or limited contribution to the growth of bulb, the main storage organ of photosynthates (Wang, 1990). Therefore, their removal has little effect on bulb yield. Photosynthetic rate or efficiency of the remaining leaves increased after partial defoliation (Gifford and Marshall, 1973; Hodgkinson, 1974; Wang, 1990). Guo (1999) determined that the lower, heavily shaded leaves of Phalaenopsis amabilis (L.) Blume did not contribute much to flowering. Harvesting Chamaedorea radicalis Mart. leaves resulted in a modest increase in leaf production; however, new leaves produced in the harvest treatments were significantly shorter than those in the control (Endress et al., 2004). It is not known how much the lower leaves of Aloe barbadensis contribute to the initiation and growth of new leaves.

To reduce production costs, it is not uncommon for aloe fields to receive no fertilizer. Growers sometimes complain about small leaves and low yield in their fields. In addition, questions have been raised about whether soil $\mathrm{pH}$ affects aloe plant growth. Although Wang and Strong (1995) studied the fluctuation of minerals, malic acid, and sugars in aloe leaves over a 2-year period, there has been no information in the scientific literature addressing how harvest technique and nutrient supply may affect aloe performance in the field. Understanding the basic plant behavior would allow for the development of better management strategies for high yields and increased profits.

The objectives of this study were to determine the long-term effects of harvesting leaves to various degrees, supplemental feeding of mineral nutrients, and the application of powdered sulfur on the rate of leaf initiation, leaf growth, and harvestable leaf yield of Aloe barbadensis.

\section{Materials and Methods} Kandelia candel (L.) Druce (Tong et al., 2003). Partial defoliation of 'McIntosh' apple (Malus domestica Borkh.) to various degrees resulted in smaller cross-sectional trunk area and reduced fruit yield (Kappel and Proctor, 1986). Fruiting during the following year was negatively affected by leaf removal during the previous year. Bulb size of tulip (Tulipa sp.) was reduced proportionally by the percentage of leaf area removed (Rees, 1972). 
in the center of a 57-L pot. Pots were placed $90 \mathrm{~cm}$ apart from center to center and irrigated when needed with the local municipal water having an electrical conductivity ranging between 0.9 and $1.4 \mathrm{dS} \cdot \mathrm{m}^{-1}$.

\section{Expt. 1}

Leaf number and nutrient supply. This experiment was a factorial arrangement with two levels of fertility and three levels of harvest under full sunlight. Half of the plants received a monthly application of a $20 \mathrm{~N}-$ 8.6P-16.6K Peters soluble fertilizer (Scotts, Marysville, $\mathrm{OH})$ at $10 \mathrm{~g}$ per pot. The other half of the test plants remained unfertilized for the duration of this study. Beginning in June 1994 and for the next 3 years, the lower leaves were harvested every 3 months to leave 18,15 , or 12 leaves on a plant. Leaf count started from inside out with the smallest visible leaf being counted as number one. At the final harvest in Mar. 1997, all plants were harvested to a uniform 12 leaves. At each harvest, the number of leaves being harvested and their combined fresh weight were recorded. These data were used to calculate the average leaf weight at each harvest and to establish the cumulative leaf yield. Also, at each harvest, suckers on each plant were removed, their numbers determined, and fresh weight recorded.

This experiment was a randomized complete block design and treatments were replicated 12 times. A single plant in a pot represented an experimental unit. Data were subjected to analysis of variance using SAS programming (SAS Institute, Cary, NC) and Duncan's multiple range test was used for mean separation.

\section{Expt. 2}

Fertilizer, micronutrient, and sulfur. Aloe barbadensis plants were planted as described previously. This factorial experiment consisted of two levels of fertilization (as described in Expt. 1), with or without a micronutrient mix (Micromax; Grace-Sierra Horticultural Products, Milpitas, CA; $25 \mathrm{~g}$ per pot, one application yearly), and four levels of powdered sulfur $(0,25,50$, or $100 \mathrm{~g}$ per pot once annually). Sulfur was added to determine if it would lower soil $\mathrm{pH}$ and be beneficial to leaf yield. There were a total of 16 treatments arranged in a randomized complete block design with eight replications. Each experimental unit consisted of a single plant per pot. Plants were placed on the floor of a greenhouse, which was covered with one layer each of a polypropylene shade fabric with a $30 \%$ light exclusion and $0.152-\mathrm{mm}$ thickness polyethylene cloth.

Harvesting, conducted every $\approx 3$ months, was initiated on 8 Aug. 1994 and ended on 29 Feb. 1996. All plants were harvested to 18 leaves at each harvest. Data were recorded as those in Expt. 1. Severity of cold injury on leaves was evaluated before the Feb. 1996 harvest. At the end of this experiment, two soil columns were collected from each pot on opposite sides. A saturated paste was made with each sample and was allowed to stand at room temperature overnight. Vacuum was applied to the saturated paste to extract the soil solution for determining the $\mathrm{pH}$. Data were analyzed similar to those in Expt. 1.

\section{Results}

Expt. 1

The youngest visible leaf was used as a common reference for determining the leaf number remaining at each harvest. Therefore, the number of leaves initiated yearly could be estimated by adding the number of leaves harvested for any given four consecutive quarters, excluding the first and last harvests. The total number of leaves harvested during the 3-year period was more than doubled by the supplemental nutrient application

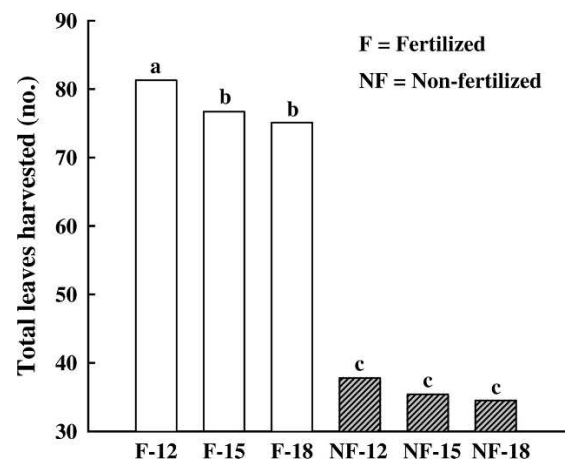

Fig. 1. Number of total harvested leaves as affected by fertilization and the number of leaves remaining $(12,15$, or 18$)$ after each harvest. Histograms with different letters are significantly different at $P=0.05$.
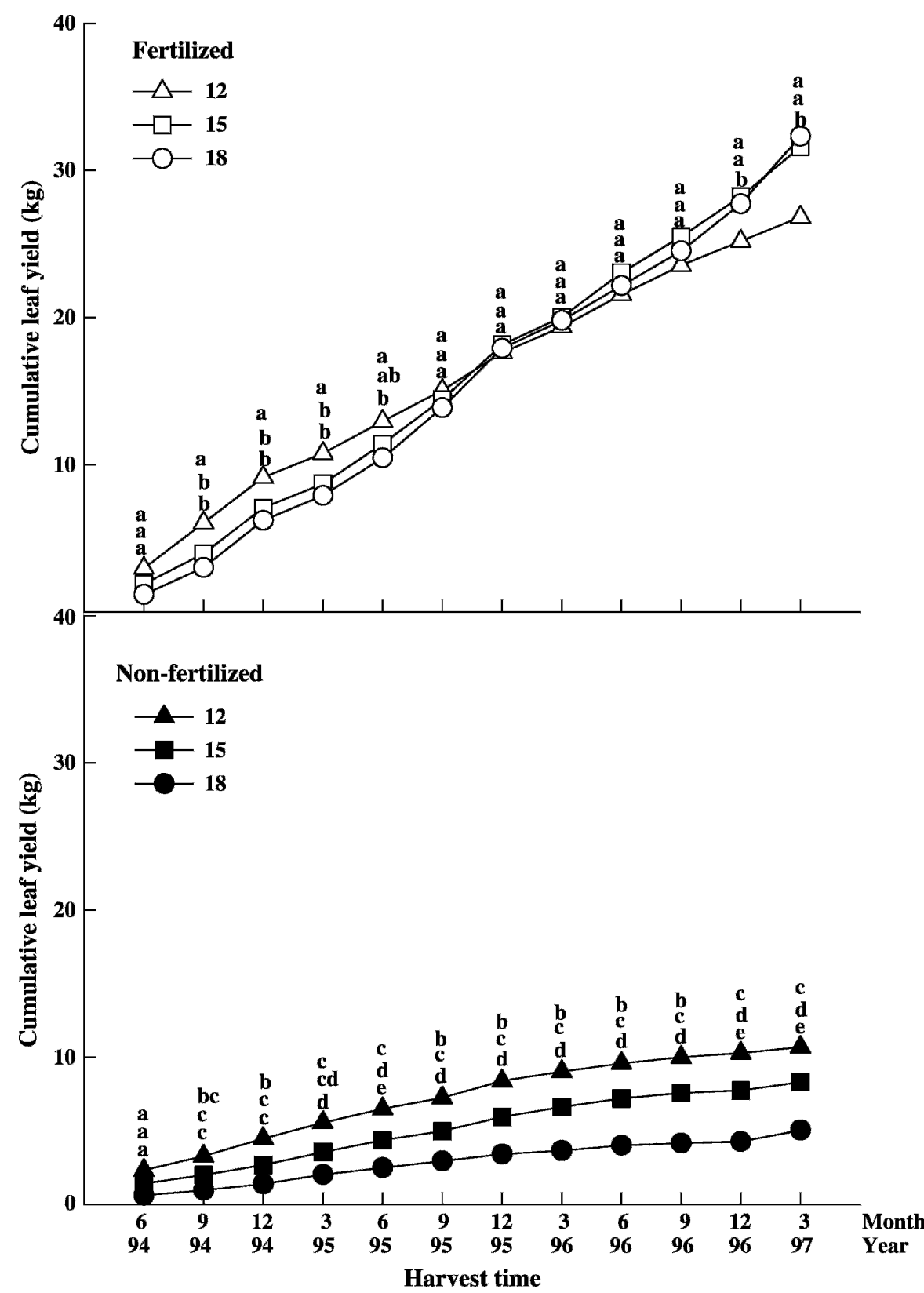

Fig. 2. Cumulative weight of harvested leaves during a 3-year period as affected by the fertilization and the number of leaves remaining $(12,15$, or 18$)$ after harvest. Data points within a given harvest date and with different letters are significantly different at $P=0.05$. 


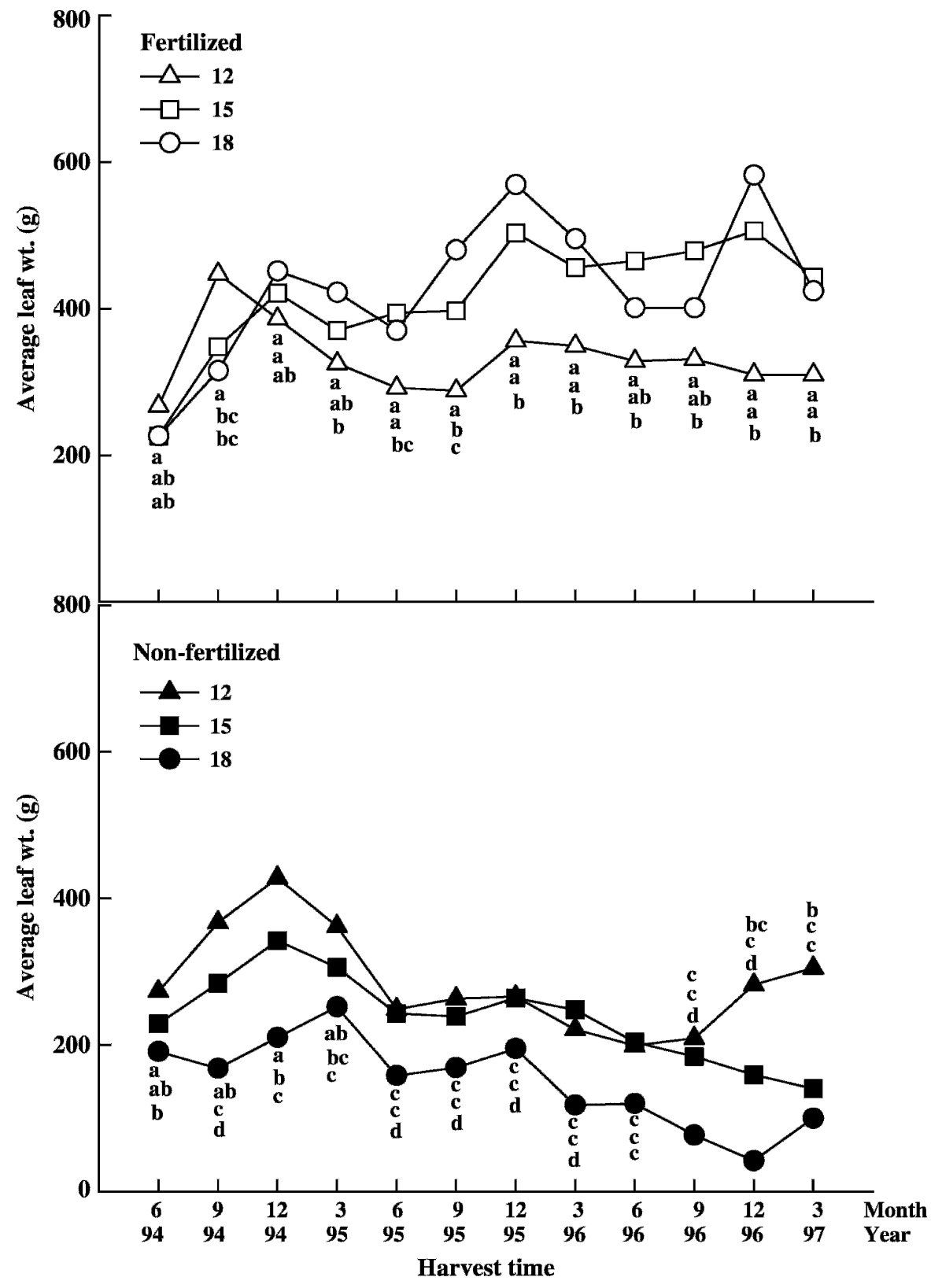

Fig. 3. Average leaf weight at each harvest during a 3-year period as a function of fertilization and number of leaves remaining $(12,15$, or 18$)$ after each harvest. Data points within a given harvest date and with different letters are significantly different at $P=0.05$.

(Fig. 1). Over the 3 years, slightly more leaves (5) were initiated by the fertilized plants harvested to 12 than to 15 or 18 leaves. The annual rate of leaf initiation averaged 24 ( $\approx 2$ per month) and $11(\approx 1$ per month) for the fertilized and nonfertilized plants, respectively. Based of these rates, the outer leaves on fertilized plants harvested to 12,15 , and 18 leaves were $\approx 9,10.5$, and 12 months old, respectively, at the time of harvest. Leaves harvested from all nonfertilized plants were 1.25 to 1.75 years old.

Over a period of 3 years, more than twice as many leaves (76 versus 36 per plant; Fig. 1) were harvested and three times as much in leaf weight (32.3 versus $10.7 \mathrm{~kg}$ per plant; Fig. 2) were obtained from plants that received fertilization than the best nonfertilized plants being harvested to 12 leaves. The lative leaf weight yield from the nonfertilized plants decreased $(5.0 \mathrm{~kg}$ per plant per year) when the number of leaves remaining increased from 12 to 18 . This decreased yield in the less severely harvested, nonfertilized plants was mainly attributable to desiccation of the lower and older leaves between harvests as shown by the low individual leaf weight as leaf remaining increased from 12 to 18 (Fig. 3).

Individual leaf weight on fertilized plants increased as harvest progressed from March to December of each year (Fig. 3). However, in nonfertilized plants, average leaf weight declined after three harvests as a result of shriveling and desiccation of the older leaves.

In fertilized plants, the number of leaves harvested was lowest in Mar. 1995 and 1996 (Fig. 4), which corresponded to their lower total leaf weights (Fig. 5) than their respective preceding harvest (December). Leaf weight was highest in December (Fig. 5). There was no such a trend in the nonfertilized plants.

In fertilized plants, the weight of harvested leaves (Fig. 5) from plants cut to 12 leaves declined after three harvests. Except for the first three harvests, total leaf weight at each harvest was higher from plants with 15 or 18 leaves remaining (Fig. 5). Leaves on plants that received supplemental nutrients were plump and green, whereas on the nonfertilized plants, leaves were thin and brownish with dried tips. These leaves had little or no usable translucent inner tissue. This condition was increasingly severe because leaves remaining on plants increased from 12 to 18 , which accounted for the lower combined leaf weight from plants with 18 leaves at most harvests (Fig. 5). In general, percentage dry matter in the gel was higher in harvested leaves from plants with 18 leaves remaining (data not shown).

Plants receiving fertilizer had superficial injury (scalding) on the abaxial side of some leaves facing the south after brief exposures to freezing temperatures in Jan. 1996 and 1997.

Fertilization greatly increased the number and weight of suckers being produced (data not shown). Leaf number remaining on plants did not affect the number of suckers. However, there appears to be a trend that, with supplemental nutrients, as increasing numbers of leaves were left intact, the average weight of each sucker also increased.

\section{Expt. 2}

Plants that received fertilizer produced more than twice the number of leaves and over three times the harvested leaf weight than the nonfertilized plants (Table 1), similar to those found in Expt. 1. The addition of micronutrients had no effect on plant growth When fertilizer was applied, adding $100 \mathrm{~g} / \mathrm{pot}$ of sulfur resulted in slower leaf initiation rate and less total leaf weight, yielding only twothirds the weight of plants that did not receive sulfur. Sulfur had no effect on either the number of leaves harvested or leaf weight yield in nonfertilized plants. Weights of individual 


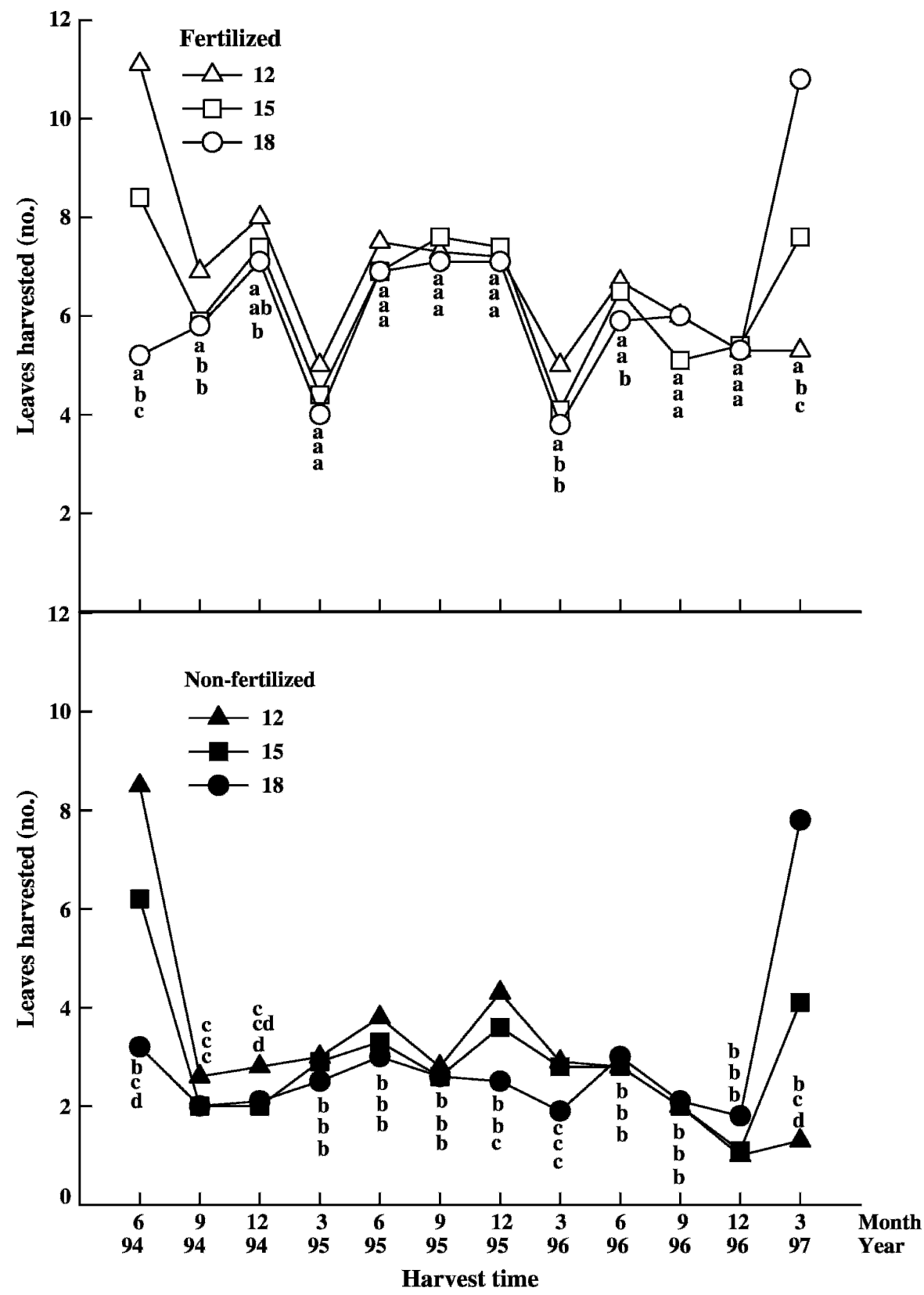

Fig. 4. Number of leaves harvested at 3-month intervals as a function of leaves remaining $(12,15$, or 18$)$ and the application of fertilizer. Data points within a given harvest date and with different letters are significantly different at $P=0.05$.

leaves were unaffected by sulfur regardless of supplemental fertilization. Plants that received fertilizer were less cold-hardy and had light cold injury on leaves (Table 1).

When fertilizer was applied, soil $\mathrm{pH}$ declined from 7.6 to 4.6 regardless of the rate of sulfur applied (Table 1). Soil $\mathrm{pH}$ was unaffected by sulfur when fertilization was withheld with the exception of the $100 \mathrm{~g} / \mathrm{pot}$ sulfur rate, which resulted in a low $\mathrm{pH}$ of 5.40 .

\section{Discussion}

The results from this study show that harvesting Aloe barbadensis severely to 12 leaves slightly enhanced leaf initiation rate over a 3 -year period. When needed under commercially conditions, aloe leaves may be harvested time eventually results in decreased leaf size and reduced gel yield (Fig. 4)

Although the rate of leaf initiation was unaffected by several severe harvests, it was increased by fertilization. The worst problem with plants that were not given supplemental nutrients was the slow leaf initiation rate (Table 1). As a result, the older, outer leaves were left on plants much longer before being harvested than on plants that were fertilized. These small, aged leaves appeared brownish and became desiccated before they could be harvested, resulting in very low leaf yield and little or no gel recovery. This was more of a serious problem for plants that had increasing numbers of leaves remaining because the older leaves desiccated before being harvested. On the other hand, plants receiving fertilization are less cold-hardy than nonfertilized plants. Therefore, supplemental fertilizer should be periodically applied to aloe fields at least during the spring and summer to promote leaf initiation and maintain high yield.

Guo (1999) found that leaves of Phalaenopsis amabilis (L.) Blume, an orchid species that also possesses the crasulacean acid metabolism pathway like Aloe barbadensis, progressively lose their photosynthetic capacity as they age. The sixth leaf had only $35 \%$ of the total daily $\mathrm{CO}_{2}$ uptake as that of the youngest mature leaf. The lower leaves of Lilium longiflorum Thumb. 'Nellie White' also were not as efficient as the upper leaves in supporting bulb growth and removing the lower 40 of the 70 total leaves did not affect bulb size (Wang, 1990). Although photosynthetic rate of aloe leaves was not determined in this study, its older, lower leaves might also have lower photosynthetic rate than the upper ones, particularly those on the nonfertilized plants. This might explain the minimal impact of short-term severe harvest of the lower leaves on yield.

Marlatt (1974) found that Sensevieria trifasciata (de Wildm.) N. E. Br. cv. Laurentii developed chilling injury (CI) symptoms of white lesions after exposure to 2 to $8{ }^{\circ} \mathrm{C}$. Although Marlatt found symptoms of chilling in Sensevieria trifasciata became more severe with increasing levels of nitrogen and potassium applications, Conover and Poole (1976) determined that increased tissue nitrogen and decreased levels of calcium were mostly closely associated with increased CI. These observations are consistent with the more severe CI found on the fertilized aloe plants.

Because the $20 \mathrm{~N}-8.6 \mathrm{P}-16.6 \mathrm{~K}$ water-soluble fertilizer used in this study is a physiological acidic fertilizer, it is not surprising to see the declined $\mathrm{pH}$ over time (Table 1). The results of the second experiment suggest that there is no apparent benefit of applying powdered sulfur and micronutrients, whether or not plants are fertilized. Simply decreasing soil $\mathrm{pH}$ does not appear to stimulate aloe growth.

\section{Recommendations}

Based on the results of this study, it is recommended that Aloe barbadensis plants 


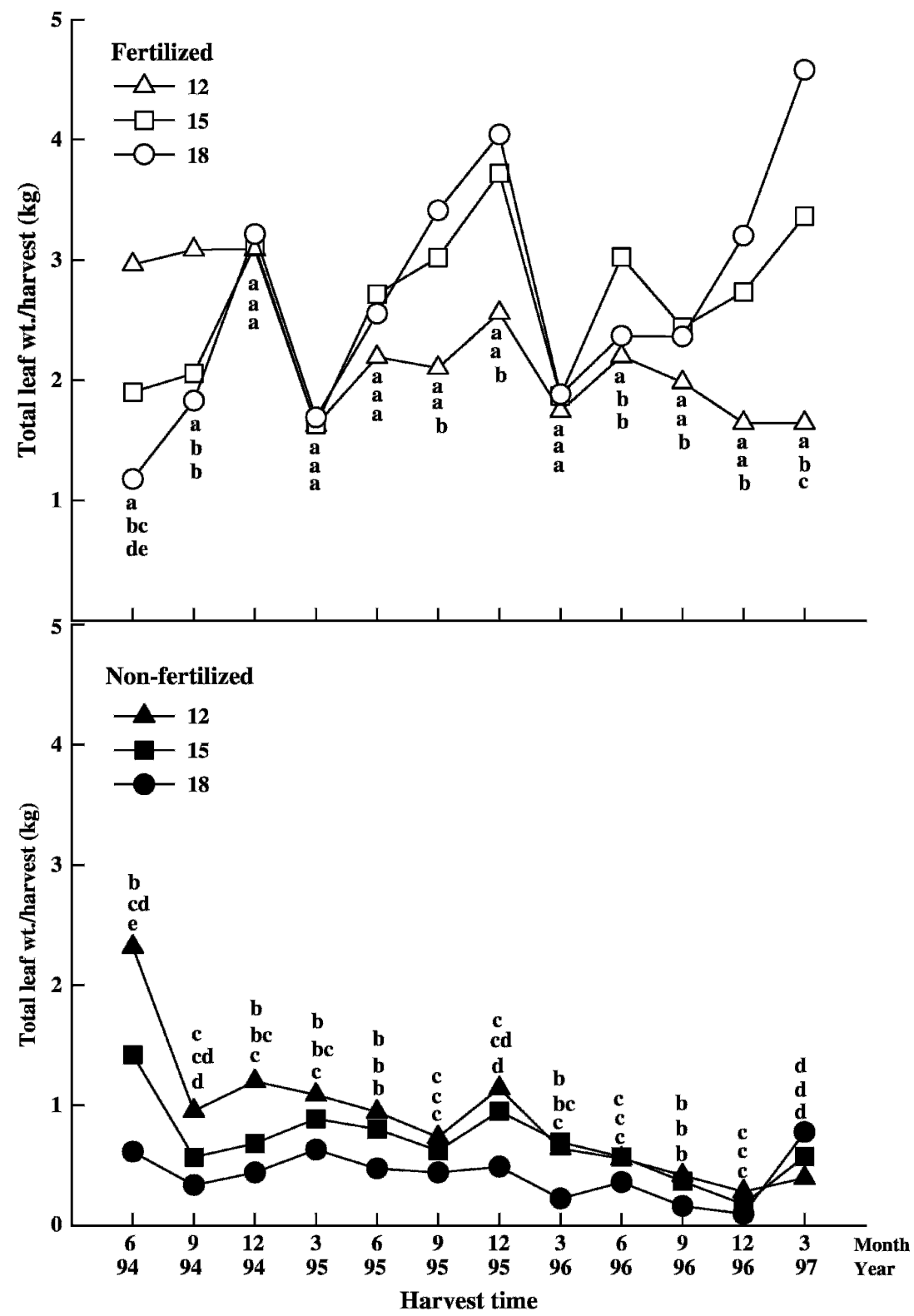

Fig. 5. Total weight of all harvested leaves at each harvest as affected by severity of harvest $(12,15$, or 18 leaves remaining after each harvest) and fertilization. Data points within a given harvest date and with different letters are significantly different at $P=0.05$.

Table 1. Effects of sulfur and supplemental nutrient application on soil $\mathrm{pH}$ and leaf yield of Aloe barbadensis. $^{2}$

\begin{tabular}{|c|c|c|c|c|c|c|}
\hline \multirow[b]{2}{*}{$\begin{array}{l}\text { Sulfur rate } \\
\text { (g/pot) }\end{array}$} & \multirow[b]{2}{*}{ Final $\mathrm{pH}^{\mathrm{y}}$} & \multicolumn{5}{|c|}{ Combined yields } \\
\hline & & $\begin{array}{c}\text { Total harvested } \\
\text { leaves (no.) }\end{array}$ & $\begin{array}{l}\text { Total leaf yield } \\
\text { (kg/plant) }\end{array}$ & $\begin{array}{c}\text { Avg leaf wt } \\
\text { (g/leaf) }\end{array}$ & $\begin{array}{l}\text { Leaf length } \\
(\mathrm{cm})\end{array}$ & $\begin{array}{l}\text { Injury rating } \\
(1-5)^{x}\end{array}$ \\
\hline & & & Fertilized & & & \\
\hline 0 & $4.92 \mathrm{a}^{\mathrm{w}}$ & $38 \mathrm{a}$ & $15.1 \mathrm{a}$ & $397 \mathrm{a}$ & $55.4 \mathrm{a}$ & $0.67 \mathrm{a}$ \\
\hline 25 & $4.57 \mathrm{a}$ & $36 \mathrm{~b}$ & $13.8 \mathrm{a}$ & $384 \mathrm{a}$ & $55.6 \mathrm{a}$ & $0.69 \mathrm{a}$ \\
\hline 50 & $4.25 \mathrm{a}$ & $36 \mathrm{~b}$ & $13.2 \mathrm{a}$ & $367 \mathrm{a}$ & $55.6 \mathrm{a}$ & $0.63 \mathrm{a}$ \\
\hline 100 & $4.57 \mathrm{a}$ & $30 \mathrm{c}$ & $10.4 \mathrm{~b}$ & $348 \mathrm{a}$ & $55.1 \mathrm{a}$ & $0.57 \mathrm{a}$ \\
\hline Average & $4.58 \mathrm{~B}^{\mathrm{v}}$ & $35 \mathrm{~A}$ & $\begin{array}{c}13.1 \mathrm{~A} \\
\text { Nonfertilized }\end{array}$ & $375 \mathrm{~A}$ & $55.4 \mathrm{~A}$ & $0.62 \mathrm{~A}$ \\
\hline 0 & $7.70 \mathrm{a}$ & $18 \mathrm{a}$ & $3.8 \mathrm{a}$ & $213 \mathrm{a}$ & $41.6 \mathrm{a}$ & $0.07 \mathrm{a}$ \\
\hline 25 & $7.54 \mathrm{a}$ & 19 a & $3.6 \mathrm{a}$ & $190 \mathrm{a}$ & $39.4 \mathrm{a}$ & $0.08 \mathrm{a}$ \\
\hline 50 & $7.47 \mathrm{a}$ & $18 \mathrm{a}$ & $3.9 \mathrm{a}$ & $215 \mathrm{a}$ & $37.6 \mathrm{a}$ & $0.07 \mathrm{a}$ \\
\hline 100 & $5.40 \mathrm{a}$ & $18 \mathrm{a}$ & $3.2 \mathrm{a}$ & $179 \mathrm{a}$ & $37.3 \mathrm{a}$ & $0.07 \mathrm{a}$ \\
\hline Average & $7.03 \mathrm{~A}$ & $18 \mathrm{~B}$ & $3.6 \mathrm{~B}$ & $202 \mathrm{~B}$ & $39.0 \mathrm{~B}$ & $0.07 \mathrm{~B}$ \\
\hline
\end{tabular}

${ }^{\mathrm{z} C u m u l a t i v e ~ y i e l d s ~ w e r e ~ f r o m ~ s e v e n ~ h a r v e s t s, ~ e v e r y ~} \approx 3$ months, between 8 Aug. 1994 and 29 Feb. 1996.

${ }^{\mathrm{y}}$ The initial soil $\mathrm{pH}$ was 7.6.

${ }^{\mathrm{x}} 0=$ no injury, $5=$ severe injury.

${ }^{\text {w} M e a n s, ~ w i t h i n ~ f e r t i l i z e r ~ t r e a t m e n t ~ a n d ~ c o l u m n, ~ w i t h ~ t h e ~ s a m e ~ l o w e r ~ c a s e ~ l e t t e r s ~ a r e ~ n o t ~ d i f f e r e n t ~ a t ~} P \leq$ 0.05 .

${ }^{\mathrm{v}}$ Means within a column followed by different upper case letters are different at $P \leq 0.001$. should be left with at least 15 leaves, preferably 18 , after each harvest for best long-term leaf yield. Plants should be fertilized periodically to promote leaf initiation, produce large leaves, and keep the older leaves from desiccating prematurely. If not fertilized, fewer leaves should be harvested at each time and harvests should be conducted more than four times yearly to avoid desiccation and reduced yield.

\section{Literature Cited}

Cera, L.M., J.P. Haggers, M.C. Robson, and W.J. Hagstrom. 1980. The therapeutic efficacy of Aloe vera cream (Dermaide Aloe) in thermal injuries: Two case studies. J. Amer. Animal Hospital Assn. 16:768-772.

Conover, C.A. and R.T. Poole. 1976. Influence of nutrition on yield and chilling injury of Sanseveiria. Proc. Fla. State Hort. Soc. 89: 305-307.

Dai, J. and R.E. Paull. 1990. The role of leaf development on anthurium flower growth. J. Amer. Soc. Hort. Sci. 115:901-905.

Endress, B.A., D.L. Gorchov, M.B. Peterson, and E.P. Serrano. 2004. Harvest of the palm Chamaedorea radicalis, its effects on leaf production, and implications for sustainable management. Conserv. Bio. 18:822-830.

Gifford, R.M. and C. Marshall. 1973. Photosynthesis and assimilate distribution in Lilium multiflorum Lam. following differential tiller defoliation. Aust. J. Biol. Sci. 26:517-526.

Guo, W.J. 1999. A study on characteristics of photosynthesis in Phalaenopsis. Dept. of Horticulture, National Taiwan University, Taipei, Taiwan, ROC, MS Thesis.

Hodgkinson, K.C. 1974. Influence of partial defoliation on photosynthesis, photorespiration, and translocation by lettuce leaves of different ages. Aust. J. Plant Physiol. 1:561-578.

Kappel, F. and J.T.A. Proctor. 1986. Simulated spotted Tentiform leafminer injury and its influence on growth and fruiting of apple trees. J. Amer. Soc. Hort. Sci. 111:64-69.

Marlatt, R.B. 1974. Chilling injury in sansevieria. HortScience 9:539-540.

Rees, A.R. 1972. The growth of bulbs. Academic Press, London.

Strickland, F.M., A. Darvill, P. Albersheim, S. Eberhard, M. Pauly, and R.P. Pelley. 1999. Inhibition of UV-induced immune suppression and interleukin-10 production by plant polysaccharides. Photochem. Photobiol. 69:141147.

Tong, Y.F., S.Y. Lee, and B. Morton. 2003. Effects of artificial defoliation on growth, reproduction and leaf chemistry of the mangrove Kandelia candel. J. Tropical Eco. 19:397-406.

Wang, Y.T. 1990. Growth and leaf photosynthesis of Lilium longiflorum Thumb. 'Nellie White' in response to partial defoliation after anthesis. Acta Hort. 266:197-204.

Wang, Y.T. and K.J. Strong. 1995. A two-year study monitoring several physical and chemical properties of field-grown Aloe barbadensis Miller leaves. Subtropical Plant Sci. 47:34-38.

Winters, W.D., R. Benavides, and W.J. Clouse. 1981. Effects of aloe extracts on human normal and tumor cells in vitro. Econ. Bot. 35: 89-95. 